\title{
Effect of Standardized Nursing Interventions on the Recovery Outcomes of Patients Undergoing Thoracic Surgeries
}

\author{
${ }^{1}$ Wafaa N. Ahmed Besely, ${ }^{2} \mathrm{Heba}$ A. Ahmed Abdel Mowla
}

\begin{abstract}
Thoracic surgery is a dramatic event with great source of stress to the patient and the family; which can produce many special problems related to physical, emotional disabilities and rehabilitation of the patient. A study aim is to determine the effect of standardized nursing interventions on the recovery outcomes of patients undergoing thoracic surgeries. Quasi experimental study was used.

Setting: The study was conducted at the cardiothoracic surgery unit and cardiothoracic surgery outpatient clinic, Main University Hospital at Alexandria, Egypt. The sample comprised of 40 adult patients planned for thoracic surgeries divided equally into study and control groups, 20 patients each.

Method: Two tools were developed by the researchers; The Preoperative Learning Needs Assessment and Thoracic Surgery Patients Assessment Sheet.

Results: The results revealed that, the majority of the study and control patients had poor knowledge about modifiable life changes. In addition, there were highly significant improvements of the study group patients in relation to following the therapeutic regimen immediately after applying the standardized nursing interventions and after two weeks of hospital discharge. In conclusion, applying standardized planned nursing interventions to thoracic surgeries patients' pre and postoperatively was effective in improving thoracic surgeries patients' outcome physical parameters which in turn improve their quality of life.
\end{abstract}

Keywords: Nursing Interventions, recovery outcomes, thoracic surgeries

\section{Introduction}

Thoracic surgery, chest surgery or thoracotomy is defined as performing an incision into the chest to gain an access to the thoracic organs; most commonly the heart, lungs, esophagus, thoracic aorta, or the anterior spine such as is necessary for access to tumors in the spine ${ }^{(1)}$. Thoracic surgery is a dramatic event with great source of stress to the patient and the family; which can produce many special problems related to physical, emotional disabilities and rehabilitation of the patient ${ }^{(2)}$. Thoracic surgery causes more deaths, disability, and economic loss in industrialized nations than any other group of diseases. Thoracic disease accounts for one half of the nearly one million annual deaths as mentioned by American Thoracic Association (ATA) $2013^{(3)}$.

Thoracic surgery is widely performed in the United States. It was estimated that more than 650,000 thoracic surgeries are performed worldwide every year ${ }^{(3,4)}$. In Egypt, according to statistical records of the Main University Hospital at Alexandria it was clarified that, from total patients' admission to the different surgical units during the year 2012, approximately $49 \%$ were in need for thoracic surgical interventions as a lifesaving therapy ${ }^{(5)}$. Thoracic surgery complications may lead to increase in the hospital stay and cost. Expert nurses can play an active role in the prevention of these complications throughout the standardized procedures steps ${ }^{(6)}$.

Hines et al (2009), studied the incidence of preoperative and postoperative thoracic surgery complications in the post anesthesia care unit (PACU) ${ }^{(7)}$. They estimated that the occurrence of complications affected about $28.8 \%$ of patients. In addition, many studies were done on perioperative thoracic surgeries indicated that, there were nursing critical errors. These errors were identified to be; wrong drug administration $24 \%$, problems with airway management, as inadequate oxygenation or ineffective suctioning $16 \%$, intravenous fluids administration and disconnection errors were $6 \%$ and failure of patients monitoring $4 \%$. Therefore, nurses assume important and active roles in caring for patients during the surgical phases ${ }^{(8,9)}$.

Darrel and Welch (2009) stressed that; thoracic surgery is a major surgery and patient may experience one of the normal complications associated with major surgery and anesthesia such as the bleeding, pneumonia or infection. Also, there is a high risk for complications in patient who have serious liver or kidney problems, obesity, heavy smokers, diabetes, congestive heart failure, cerebrovascular disease and sedentary life style ${ }^{(10)}$. On the other hand, Carlson and Islam (2012) stated that, almost all patients experience some fear and anxiety when facing a thoracic surgery ${ }^{(11)}$.

Nursing intervention is a continuous process of assisting patients who have undergoing thoracic surgery and their families in an effort to reduce complaints and achieve optimal health. The term recovery has been imposed as multi-dimensional process which not only encompasses the expectation of returning to physical health and social roles, but also; includes resumption of psychological, cognitive and spiritual well-being ${ }^{(12)}$. 
Full recovery from thoracic surgery takes around two months. The first month after discharge is particularly distressful. Almost all patients experience some fear and anxiety from temporary or lasting changes in role relationships, decision making patterns and balance of power with the family, uncertainty of outcome and fear from death ${ }^{(1,12)}$.

Smith and Daper (2010) added that, during recovery process, patients complain lots of physical discomfort as sleep disturbance, change in bowel habits, altered mobility and change in appetite, shortness of breath, and mood swings ${ }^{(13)}$. As a result of these symptoms, patients cannot resume usual activities, delaying their return to previous role and unable to accept and deal with life changes. In addition, Mitcheel and Zellweger (2001) stressed that the patients undergoing thoracic surgery can improve their health and lessen their likelihood of further postoperative complications through instruction and information about life style changes after surgery (14). These instructions include eating a healthy diet; restriction of smoking; exercising regularly; take all medications exactly as prescribed; and follow up the doctor by regular visits. Patients undergoing thoracic surgeries should receive nursing information about mediations, laboratory investigations, and how to deal with changes in their conditions after surgery ${ }^{(15,16,17,18)}$.

The emphasis during preoperative phase should be based upon the correction of the physiological and psychological problems that might increase surgical risk. Patient's teaching regarding thoracic surgery related instructions and demonstration of exercises that help the patient during postoperative period should also be completed ${ }^{(19,20,21,22,23)}$.

The nurse must instruct the patients before surgery about the benefits of smoking cessation. Smoking can cause bronchopulmonary irritation, increases tracheobronchial secretions, decreases oxygen saturation and increases carboxy hemoglobin in the blood. Because oxygen saturation and minimal secretion production are important during and following thoracic surgery, the patient is advised not to smoke during the pre and postoperative periods ${ }^{(24,25,26)}$.

\section{Aim Of The Study}

The present study aims to determine the effect of standardized nursing interventions on the recovery outcomes of patients undergoing thoracic surgeries.

Operational definitions

Recovery outcomes: It is defined as patient return to his normal physical and psychological health status after surgery. It is manifested with several parameters: Physical: Hemodynamic stability as evidenced by (vital signs within normal ranges, maintain body weight within normal range and demonstrate muscles and joints strength). Follow the prescribed diet, exercises, medications, using the learned relaxation techniques and restrict smoking $(1,25)$.

Standardized nursing interventions: It included the following: ${ }^{(19)}$

1. Preoperative nursing instructions regarding the operation, wound incision, importance of early ambulation, breathing and coughing exercises and movement in bed and out of bed after surgery.

2. Postoperative nursing care through provision of exercises for joints and muscles as well as nursing instructions before discharge regarding diet therapy, smoking restrictions, exercises and medications.

Research hypothesis: Following the standardized nursing interventions would improve the recovery outcomes of patients undergoing thoracic surgeries.

\section{Materials and Method}

Study design: Quasi experimental study was used to investigate the effect of standardized nursing interventions on the recovery outcomes of patients undergoing thoracic surgeries.

Setting: The study was conducted at the cardiothoracic surgery unit and cardiothoracic surgery outpatient clinic, in the Main University Hospital at Alexandria, Egypt.

Subjects: The study subjects were entailing a convenience sample of 40 adult patients planned for thoracic surgeries. They divided equally into study and control groups 20 patients each from adult patients, their ages ranging from 30 to 60 years old and planned for thoracic surgeries for the first time.

Tools: Two tools were developed by the researchers based on the review of recent related literature to collect the necessary data for this study.

Tool 1: Preoperative Learning Needs Assessment. This tool was developed to elicit the patients' learning needs as pre-requisites for preoperative and postoperative nursing interventions as well as follow up comparison. It 
included questions related to diet, exercises, smoking as well as medications ${ }^{(1,19,22)}$. Socio-demographic data was attached to this tool.

Tool 2: Thoracic Surgery Patients Assessment Sheet. It has two parts:

Part 1: Physical outcome: Patient's postoperative clinical profile. This part was used to measure the physical status of patients postoperatively. It was including the following: Body weight in $\mathrm{kg}$ and Body Mass Index by using formula (body weight in $(\mathrm{kg}) /$ Height in meter $(\mathrm{m})^{2}=\mathrm{kg} / \mathrm{m}^{2}$. Muscles strength was identified by a Likert Scale developed by Lovtt $(1998)^{(26)}$ to determine strength of patient muscles before and after carrying out the exercises. This part was also comprised of vital signs and fluid intake and output.

Part 2: Therapeutic and psychosocial behavior outcome. This part includes the following items:

Exercises and activity: This part was developed in order to determine the patient level of tolerance before and after performing physical exercises postoperatively as following parameters: Heart rate and blood pressure is neither $>160 / 100$ nor $<90 / 60 \mathrm{mmHg}$ or heart rate is neither $>110$ nor $<60 \mathrm{~b} / \mathrm{m}$, respiratory rate neither exceeding $30 \mathrm{c} / \mathrm{m}$ nor less than $10 \mathrm{c} / \mathrm{m}$., patient complaints of chest pain, shortness of breath, nausea, dizziness, inability to talk while exercise, abnormal sweating, pallor or exhaustion and rating of perceived exertion scale. This scale was developed by Borg (1996) to determine patient rate of exertion level during performing physical exercise $^{(27)}$.

Smoking: Current smoking status assessment. This part was developed by the investigators based on relevant literature $^{(20,23)}$ to assess patients' current smoking habits. Two open ended questions were asked about the frequency of smoking before surgery and its effect on his/her condition. It was contained three responses rating from (1) which denotes (always), (2) which indicates sometimes and (3) which denotes (rarely).

Activity assessment: this part was developed to determine patients' adherence to the given instructions related to the daily activity and exercises that should be done after thoracic surgery. It was consisted of list of daily activities that the patient has to avoid and permissible activities ${ }^{(28,29)}$.

Medications: This part was developed to follow prescribed medications. It was included six open ended questions about the names of drugs administered, the prescribed dose, the proper frequency and time, actions, and side effects of the drugs ${ }^{(29)}$.

\section{Method}

1. Written permission to carry out the study was obtained from the responsible authorities of hospital after explanations of the purpose of the study.

2. The tools of data collection (I and II) were developed by the researchers after review of the recent literature and revised by 9 experts specialized in the field of cardiothoracic surgery of nursing and medicine in Alexandria University for their content validity. The necessary modifications were done accordingly.

3. Patient consent to participate in the study was obtained after explanations of the purpose of the study.

4. Patients were randomly and equally divided into a study and control groups. Both groups were matched as much as possible regarding age, sex and level of education.

5. Pilot study carried out after the development of the tools on 5 patients who scheduled for thoracic surgery to evaluate the clarity and applicability of the tools. It was conducted two months before data collection.

6. The data obtained from the pilot study were analyzed manually. It was evident that the statements of the preoperative interview schedule and postoperative were relevant in tool II, some items have been added and others were modified to be clear and understood.

7. The actual study was implemented through four phases:

Assessment phase: After assessment of relevance of interview assessment sheet (Tool I) preoperatively, every patient in both groups who fulfilled the study criteria was interviewed and was assessed to identify their postoperative learning needs for suitable nursing interventions.

Planning phase: The nursing interventions were constructed and thoracic surgery manual was developed by the researchers for patients undergoing thoracic surgeries. This manual was in Arabic and based on review of relevant literature and based on the results of patients' learning needs. It covered the following aspects (diet, restrict smoking activity and exercises, and medications) $(20,28,29)$.

Implementation phase:_Patients in the control group was recruited initially and watched for the routine hospital nursing interventions. The standardized nursing interventions provided only to the study group in two phases as follows: 


\section{Preoperative preparations:}

Every patient of the study group was interviewed individually preoperatively in the inpatient ward at the day of admission. Starting session was about 30 minutes through which the researcher gave instructions (these instructions not given as a routine by working nurses might be because of their low educational preparation or due to their work overload) and simple information regarding:

- The site of operation for wound incision according to doctors' order and the time of operation.

- Orientation to intensive care unit and equipment which will be connected for short period of time as mechanical ventilator, cardiac monitor, nasogastric tube, urinary catheter, chest tube and drainage tubes.

- Diet that should be given before the operation as increase warm fluid and eating light soup vegetables and fasting before the operation 6 hours.

- The importance of coughing and deep breathing exercises before and after the operation and training how to perform it before the operation.

- The importance of early ambulation and movement in bed after surgery especially leg movement to prevent developing of deep vein thrombosis.

Postoperative preparations: It was started in the inpatient ward after patient discharge from the intensive care unit and it was continued until discharge. Patients were instructed about; life style changed after surgery related to recommended diet, restriction of smoking, exercises, activity and medications. These instructions were clarified and illustrated for patients through distribution of the developed thoracic surgery manual. It was done through individualized six teaching sessions on three consecutive days as follows: On the $1^{\text {st }}$ postoperative day when the patient is thermodynamically stable as indicated by surgeon permission, patients of both groups were assessed basically by using tool II part one.

- $\quad$ Vital signs, fluid intake and output for 24 hours were measured for every patient.

- Every patient in the study group was seen by the researchers individually on the fourth day postoperative in the ward for applying postoperative range of motion and muscle exercises in three sessions for about 30 minutes each and continued for three consecutive days. Every patient of the study group assessed physically using (Tool II part 2A) by measuring apical pulse, blood pressure and respiratory rate before and after doing exercises, assessing patient complaints and patient rate of exertion level during performing postoperative physical exercise by using Borg Scale (1996) ${ }^{(27)}$.

- Before applying designed nursing intervention, each patient of both groups was interviewed by the researchers to assess their knowledge regarding the prescribed regimen, using part 2 (B, C, and D). Assessment of patients of both groups physically by using (Tool II part 1).

- Every patient in the study group was instructed by the researchers regarding changes in their life after surgery by using the content of developed nursing intervention phase (2) which distributed on three individualized teaching sessions on three consecutive days before discharge about 20 minutes each.

- The intervention was explained by the researchers and family members who accompanied some patients in the study group were encouraged and allowed to attend the learning sessions.

- The first session was summarized as introduction about patients' condition after surgery and importance of introducing some habits and modifies patients' life style after hospital discharge. At the end of this session the patient should identify the diet that should be eaten and diet that should be restricted, types of smoking and the importance of weight control. So, in this session the patient received simple clear information about:

Smoking restriction: the patient was informed as regard: action of smoking (nicotine) and its effects on his/her chest condition. Diet therapy and importance of weight control and avoidance of obesity was also stressed.

The second session covered the postoperative physical exercises and muscles setting exercises. Also, instructions about medications were added. At the end of this session the patient should perform postoperative exercises, identify name, dose, side effect of medications given and the activities should be done. So, in this session the patient should perform postoperative exercises after discharge and its effect on the early recovery outcome. In addition; the importance of muscles setting exercises and its effect on wound healing.

The third session consisted of items related to wound care and the avoidance of its exposure to infection. In this session the patient should be identify signs and symptoms of infection and demonstrate the care of wound. Furthermore; the importance of regular medical checks up on periodic intervals in the outpatient or private clinic.

The teaching sessions were arranged and explained to the patients according to their level of education and were supplemented with needed illustrations. The developed manual was given to the patients at the end of sessions before hospital discharge.

Collection of data was carried out through a period of six months from the beginning of August 2012 till the end of January 2013. 


\section{Evaluation phase:}

- Prior to discharge and immediate post applying standardized nursing interventions, each patient of both groups were interviewed to assess their knowledge regarding the prescribed regimen, using part 2 ( $\mathrm{B}, \mathrm{C}$ and D). Assessment of patients of both groups physically by using (Tool II part 1).

- After two weeks of discharge patients of both groups were reassessed by measuring their weight, height, and vital signs. Then patients interviewed at the outpatient clinic to determine their adherence to the instructions and their effect on their outcomes using tool II part 1 and part 2 (B, C and D).

- Thirty days post discharge, the thoracic surgery assessment sheet was reutilized for both group members attending patients at the outpatient clinics as a late follow up.

- The patient recovery outcomes evaluated according to the identified parameters.

- Each group outcome parameters were checked before and after implementing the nursing interventions then differences in both groups were statistically compared.

Statistical analysis:

After collection, data were coded and transformed into a specially designed format so as to be suitable for computer feeding. The statistical package for social sciences (SPSS) version 20 for windows was used for data analysis.

The level of significance selected for this study was $\mathrm{P} \geq 0.05$ and the following statistical measures were used:

- Number and percent distribution were done for biosociodemographic data; mean $\left.{ }_{\mathrm{x}} \mathrm{x}\right)$ and standard deviation $( \pm \mathrm{SD})$ were done for all parameters of data.

- The chi square $\left(\mathrm{X}^{2}\right)$ test as a non-parametric test was used to compare differences in distribution of frequency among study and control groups.

- T test was used as parametric test for significant.

- The Wilcoxon signed ranked test is used to quantitative variables.

- Paired studied (t) test for comparing changes between two readings in the same group.

- The Fisher's exact test was used as a non-parametric test of significance for comparison between the distributions of two qualitative variables whenever the $\left(X^{2}\right)$ test was not appropriate (less than $20 \%$ of the expected count less than 5).

- McNemer Chi-square test is used for assessing the effectiveness of nursing interventions differences.

- Spearman correlation coefficient test measure the degree of association between qualitative values.

\section{Results}

Table (1) illustrates the distribution of the percentage of both groups according to their Sociodemographic characteristics. From this table, it was observed that about half of patients in both groups $(52.5 \%)$ were in the age group of more than 50 years old. Regarding sex, $75 \%$ of patients were males. As regards occupation, it was noticed that $67.5 \%$ of patients were manual workers and only $10 \%$ were professional workers. Regarding the education level, it was observed that, $40 \%$ of patients had elementary education, while only $12.5 \%$ had university education. Considering marital status, it was observed that $80 \%$ of the included patients were married. As regards the income, the majority of patients (67.5\%) their monthly incomes were not enough.

Table (1) Distribution of the Percentage of both groups according to their Sociodemographic Characteristics

\begin{tabular}{|c|c|c|c|c|c|c|c|}
\hline \multirow[t]{2}{*}{ Variable } & \multicolumn{2}{|c|}{$\begin{array}{l}\text { Study group } \\
n=20\end{array}$} & \multicolumn{2}{|c|}{$\begin{array}{l}\text { Control group } \\
n=20\end{array}$} & \multicolumn{2}{|c|}{$\begin{array}{l}\text { Total } \\
\mathrm{n}=40\end{array}$} & \multirow{2}{*}{$\begin{array}{l}X^{2} \\
\text { (P) }\end{array}$} \\
\hline & NO. & $\%$ & NO. & \%\% & NO. & $\%$ & \\
\hline $\begin{array}{l}\text { Age in years } \\
-30>40 \\
-40>50 \\
-50+\end{array}$ & $\begin{array}{l}3 \\
7 \\
10\end{array}$ & $\begin{array}{l}15 \\
35 \\
50\end{array}$ & $\begin{array}{l}1 \\
8 \\
11\end{array}$ & $\begin{array}{l}5 \\
40 \\
55\end{array}$ & $\begin{array}{l}4 \\
15 \\
21\end{array}$ & $\begin{array}{l}10 \\
37.5 \\
52.5\end{array}$ & $\begin{array}{l}0.230 \\
(0.8)\end{array}$ \\
\hline $\begin{array}{l}\text { Sex } \\
\text { - Male } \\
\text { - Female } \\
\end{array}$ & $\begin{array}{l}15 \\
5\end{array}$ & $\begin{array}{l}75 \\
25 \\
\end{array}$ & $\begin{array}{l}15 \\
5 \\
\end{array}$ & $\begin{array}{l}75 \\
25 \\
\end{array}$ & $\begin{array}{l}30 \\
10\end{array}$ & $\begin{array}{l}75 \\
25 \\
\end{array}$ & $\begin{array}{l}0.000 \\
(1.0)\end{array}$ \\
\hline $\begin{array}{l}\text { Occupation } \\
\text { - Not work/Housewives } \\
\text { - Manual work } \\
\text { - Clerical work } \\
\text { - Professional work }\end{array}$ & $\begin{array}{l}3 \\
16 \\
0 \\
1\end{array}$ & $\begin{array}{l}15 \\
80 \\
0 \\
5\end{array}$ & $\begin{array}{l}3 \\
11 \\
3 \\
3\end{array}$ & $\begin{array}{l}15 \\
55 \\
15 \\
15\end{array}$ & $\begin{array}{l}6 \\
27 \\
3 \\
4\end{array}$ & $\begin{array}{l}15 \\
67.5 \\
7.5 \\
10\end{array}$ & $\begin{array}{l}9.5 \\
(0.4)\end{array}$ \\
\hline $\begin{array}{l}\text { Educational level } \\
\text { - Illiterate } \\
\text { - Read and write } \\
\text { - Elementary } \\
\text { - Secondary } \\
\text { - University }\end{array}$ & $\begin{array}{l}6 \\
3 \\
8 \\
2 \\
1\end{array}$ & $\begin{array}{l}30 \\
15 \\
40 \\
10 \\
5\end{array}$ & $\begin{array}{l}3 \\
4 \\
8 \\
1 \\
4\end{array}$ & $\begin{array}{l}15 \\
20 \\
40 \\
5 \\
20\end{array}$ & $\begin{array}{l}9 \\
7 \\
16 \\
3 \\
5\end{array}$ & $\begin{array}{l}22.5 \\
17.5 \\
40 \\
7.5 \\
12.5\end{array}$ & $\begin{array}{l}13.2 \\
(0.27)\end{array}$ \\
\hline
\end{tabular}




\begin{tabular}{|c|c|c|c|c|c|c|c|}
\hline \multirow[t]{2}{*}{ Variable } & \multicolumn{2}{|c|}{$\begin{array}{l}\text { Study group } \\
\mathrm{n}=20\end{array}$} & \multicolumn{2}{|c|}{$\begin{array}{l}\text { Control group } \\
n=20\end{array}$} & \multicolumn{2}{|c|}{$\begin{array}{l}\text { Total } \\
\mathrm{n}=40\end{array}$} & \multirow{2}{*}{$\begin{array}{l}X^{2} \\
(P)\end{array}$} \\
\hline & NO. & $\%$ & NO. & $\%$ & NO. & $\%$ & \\
\hline $\begin{array}{l}\text { Marital status } \\
\text { - Single } \\
\text { - Married } \\
\text { - Widow } \\
\end{array}$ & $\begin{array}{l}3 \\
17 \\
0 \\
\end{array}$ & $\begin{array}{c}15 \\
85 \\
0 \\
\end{array}$ & $\begin{array}{l}4 \\
15 \\
1 \\
\end{array}$ & $\begin{array}{l}20 \\
75 \\
5 \\
\end{array}$ & $\begin{array}{l}7 \\
32 \\
1 \\
\end{array}$ & $\begin{array}{l}17.5 \\
80 \\
2.5 \\
\end{array}$ & $\begin{array}{l}2.1 \\
(0.35)\end{array}$ \\
\hline $\begin{array}{l}\text { Monthly income } \\
\text { - Enough } \\
\text { - Not enough }\end{array}$ & $\begin{array}{l}8 \\
12\end{array}$ & $\begin{array}{l}40 \\
60\end{array}$ & $\begin{array}{l}5 \\
15\end{array}$ & $\begin{array}{l}25 \\
75\end{array}$ & $\begin{array}{l}13 \\
27\end{array}$ & $\begin{array}{l}32.5 \\
67.5\end{array}$ & $\begin{array}{l}0.7 \\
(0.3)\end{array}$ \\
\hline
\end{tabular}

* Significant differences at $\mathbf{P}$ level at $\leq \mathbf{0 . 0 5}$

Table 2: Illustrate distribution of the subjects (study and control groups) according to their habits. The table showed that more than half (57.5\%) of the studied patients were smoker. Moreover; a slightly more than three quarters of the studied patients were smokers since more than 20 years $(85 \%)$ and $(37.5 \%)$ of them were smoking more than three boxes per day. A statistically significant difference was found between study and control groups in relation to the item of duration of smoking by years $\left(\mathrm{X}^{2}=11.4, \mathrm{P} 0.000\right)$. Regarding the daily activity, the table showed that $60 \%$ of the studied patients were capable of? Carrying heavy objects. As regards exercises, two-third of the subjects didn't practice any exercise. In relation to medication habits the table revealed that, half of the total studied patients sometimes take their medication on time. In relation to measures taken when forgetting certain dose of medication on time, $47.5 \%$ of the total studied patients did not take any measures to overcome this mistake. On the other hand, the main observed reasons of studied patients discontinue taking their medications were when the medication not found and if they feel well $(47.5 \%)$ and $(25 \%)$ respectively.

Table 2: Illustrate distribution of the subjects (study and control groups) according to their habits.

\begin{tabular}{|c|c|c|c|c|c|c|c|}
\hline \multirow[t]{2}{*}{ Variables } & \multicolumn{2}{|c|}{$\begin{array}{l}\text { Study group } \\
\mathrm{n}=20\end{array}$} & \multicolumn{2}{|c|}{$\begin{array}{l}\text { Control group } \\
n=20\end{array}$} & \multicolumn{2}{|c|}{$\begin{array}{l}\text { Total } \\
\mathrm{n}=40\end{array}$} & \multirow{2}{*}{$\begin{array}{l}X^{2} \\
(\mathrm{P})\end{array}$} \\
\hline & NO. & $\%$ & NO. & $\%$ & NO. & $\%$ & \\
\hline \multicolumn{8}{|l|}{ Smoking habits } \\
\hline $\begin{array}{l}\text { Smoker } \\
\text { Yes } \\
\text { No }\end{array}$ & $\begin{array}{l}12 \\
8\end{array}$ & $\begin{array}{l}60 \\
40 \\
\end{array}$ & $\begin{array}{l}11 \\
9\end{array}$ & $\begin{array}{l}55 \\
45 \\
\end{array}$ & $\begin{array}{l}23 \\
17\end{array}$ & $\begin{array}{l}57.5 \\
42.5 \\
\end{array}$ & $\begin{array}{l}0.4 \\
(0.4) \\
\end{array}$ \\
\hline $\begin{array}{l}\text { Duration of smoking/year } \\
15<20 \\
20+\end{array}$ & $\begin{array}{l}1 \\
19 \\
\end{array}$ & $\begin{array}{l}5 \\
85 \\
\end{array}$ & $\begin{array}{l}5 \\
15 \\
\end{array}$ & $\begin{array}{l}25 \\
75 \\
\end{array}$ & $\begin{array}{l}6 \\
34 \\
\end{array}$ & $\begin{array}{l}15 \\
85 \\
\end{array}$ & $\begin{array}{l}11-4 \\
(0.00)^{*}\end{array}$ \\
\hline $\begin{array}{l}\text { Number of cigarette/day } \\
\text { Two boxes } \\
\text { Three boxes } \\
\text { More than } 3 \text { boxes } \\
\end{array}$ & $\begin{array}{l}3 \\
4 \\
13 \\
\end{array}$ & $\begin{array}{l}15 \\
20 \\
65 \\
\end{array}$ & $\begin{array}{l}9 \\
9 \\
2 \\
\end{array}$ & $\begin{array}{l}45 \\
45 \\
10 \\
\end{array}$ & $\begin{array}{l}12 \\
13 \\
15 \\
\end{array}$ & $\begin{array}{l}30 \\
32.5 \\
37.5 \\
\end{array}$ & $\begin{array}{l}7.8 \\
(0.2)\end{array}$ \\
\hline \multicolumn{8}{|l|}{ Activity habits } \\
\hline $\begin{array}{l}\text { Carry heavy objects (more than } 10 \mathrm{Kg} \text { ) } \\
\text { Done } \\
\text { Not done }\end{array}$ & $\begin{array}{l}12 \\
8\end{array}$ & $\begin{array}{l}60 \\
40\end{array}$ & $\begin{array}{l}12 \\
8\end{array}$ & $\begin{array}{l}60 \\
40\end{array}$ & $\begin{array}{l}24 \\
16\end{array}$ & $\begin{array}{l}60 \\
40\end{array}$ & $\begin{array}{l}3.1 \\
(0.9)\end{array}$ \\
\hline $\begin{array}{l}\text { Practice exercises } \\
\text { Done } \\
\text { Not done }\end{array}$ & $\begin{array}{l}6 \\
14\end{array}$ & $\begin{array}{l}30 \\
70\end{array}$ & $\begin{array}{l}8 \\
12 \\
\end{array}$ & $\begin{array}{l}40 \\
60\end{array}$ & $\begin{array}{l}14 \\
26\end{array}$ & $\begin{array}{l}35 \\
65 \\
\end{array}$ & $\begin{array}{l}2.7 \\
(0.6)\end{array}$ \\
\hline \multicolumn{8}{|l|}{ Medication habits } \\
\hline $\begin{array}{l}\text { Take the medication on time } \\
\text { Yes } \\
\text { Sometimes } \\
\text { No } \\
\end{array}$ & $\begin{array}{l}3 \\
10 \\
7 \\
\end{array}$ & $\begin{array}{l}15 \\
50 \\
35 \\
\end{array}$ & $\begin{array}{l}5 \\
10 \\
5 \\
\end{array}$ & $\begin{array}{l}25 \\
50 \\
25 \\
\end{array}$ & $\begin{array}{l}8 \\
20 \\
12 \\
\end{array}$ & $\begin{array}{l}20 \\
50 \\
30 \\
\end{array}$ & $\begin{array}{l}0.4 \\
(0.8)\end{array}$ \\
\hline $\begin{array}{l}\text { Measures taken when forget a dose } \\
\text { Take two doses on time of another dose } \\
\text { Take another dose in its time only } \\
\text { Stop medication taken until ask doctor } \\
\text { Take when remember } \\
\text { Nothing }\end{array}$ & $\begin{array}{l}0 \\
5 \\
2 \\
2 \\
11 \\
\end{array}$ & $\begin{array}{l}0 \\
25 \\
10 \\
10 \\
55\end{array}$ & $\begin{array}{l}0 \\
6 \\
1 \\
5 \\
8 \\
\end{array}$ & $\begin{array}{l}0 \\
30 \\
5 \\
25 \\
40 \\
\end{array}$ & $\begin{array}{l}0 \\
11 \\
3 \\
7 \\
19 \\
\end{array}$ & $\begin{array}{l}0 \\
27.5 \\
7.5 \\
17.5 \\
47.5 \\
\end{array}$ & $\begin{array}{l}3.1 \\
(0.2)\end{array}$ \\
\hline $\begin{array}{l}\text { Stop taking medication when } \\
\text { Feel well } \\
\text { Medication not found } \\
\text { Doctor order } \\
\text { Expensive }\end{array}$ & $\begin{array}{l}5 \\
10 \\
2 \\
3 \\
\end{array}$ & $\begin{array}{l}25 \\
50 \\
10 \\
15\end{array}$ & $\begin{array}{l}5 \\
9 \\
4 \\
2\end{array}$ & $\begin{array}{l}25 \\
45 \\
20 \\
10\end{array}$ & $\begin{array}{l}10 \\
19 \\
6 \\
5\end{array}$ & $\begin{array}{l}25 \\
47.5 \\
15 \\
12.5 \\
\end{array}$ & $\begin{array}{l}7.3 \\
(0.6)\end{array}$ \\
\hline
\end{tabular}

* Significant differences at $P$ level at $\leq 0.05$ 
Table 3: Illustrates comparison between pre and post-performance of postoperative exercises muscle strength of patients in the study group. This table showed that, half of patients in the study group had normal complete range of motion against gravity with full resistance after performing postoperative exercise as compared to $20 \%$ of them. A statistically significant difference between pre and post exercise muscle strength performed by the patients of the study group was found in relation to their muscle strength. $\mathrm{Z}=4.2(\mathrm{P}=0.00)$.

Table 3: Comparison between Pre and Post Performance of Postoperative Exercises Muscle Strength of Patients in the Study Group.

\begin{tabular}{|c|c|c|c|c|c|}
\hline \multirow{3}{*}{ Muscle strength description } & \multicolumn{5}{|c|}{ Study group $n=20$} \\
\hline & \multicolumn{2}{|c|}{ Post Performing exercise } & \multicolumn{2}{|c|}{ Pre performing exercise } & \multirow{2}{*}{$\begin{array}{c}\mathrm{Z} \text { - test } \\
(\mathrm{P})\end{array}$} \\
\hline & NO. & $\%$ & NO. & $\%$ & \\
\hline $\begin{array}{l}\text { - } \\
\text { exercises against gravity and resistance. }\end{array}$ & 7 & 35 & 5 & 25 & \multirow{3}{*}{$\begin{array}{c}4.2 \\
(0.00)^{*}\end{array}$} \\
\hline $\begin{array}{l}\text { - Good complete range of motion } \\
\text { against some added resistance. }\end{array}$ & 9 & 45 & 5 & 25 & \\
\hline $\begin{array}{l}\text { - Normal complete range of motion } \\
\text { against gravity with full resistance. }\end{array}$ & 4 & 20 & 10 & 50 & \\
\hline
\end{tabular}

* Significant difference at $\mathrm{P}$ level at $\leq 0.05$

Table 4: Illustrates comparison between the first and third day level of exertion postoperative for study group patients during performing exercises. This table showed that, $60 \%$ of the study group had moderate exertion during performing exercise, while $15 \%$ of them had the same level of exertion at $3^{\text {rd }}$ day post hospital discharge. In addition, 5\% of the study groups were having almost maximal exertion in $3^{\text {rd }}$ day during performing exercise. However, a statistically significant difference was found within study group between $1^{\text {st }}$ and $3^{\text {rd }}$ day postoperative during performing exercise regarding their exertion level. $\mathrm{Z}=5.5 \mathrm{P}(0.000)$.

Table 4: Comparison between the First and Third Day Level of Exertion Postoperative for Study Group Patients during Performing Exercises

\begin{tabular}{|c|c|c|c|c|c|c|}
\hline & \multirow{3}{*}{ Exertion level } & \multicolumn{5}{|c|}{ Study group $n=20$} \\
\hline & & \multicolumn{2}{|c|}{$\overline{1}^{\text {st }}$ day post hospital discharge } & \multicolumn{2}{|c|}{ (3 $^{\text {rd }}$ day post hospital discharge } & \multirow{2}{*}{$\begin{array}{l}Z-\text { test } \\
\text { (P) }\end{array}$} \\
\hline & & NO. & $\%$ & NO. & $\%$ & \\
\hline- & Very easy & 1 & 5 & 0 & 0 & \multirow{8}{*}{$\begin{array}{c}5.5 \\
(0.000)^{*}\end{array}$} \\
\hline- & Easy & 1 & 5 & 0 & 0 & \\
\hline- & Mild & 3 & 15 & 2 & 10 & \\
\hline- & Moderate & 12 & 60 & 3 & 15 & \\
\hline- & Hard & 2 & 10 & 7 & 35 & \\
\hline- & Maximal hard & 1 & 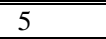 & 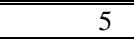 & 25 & \\
\hline 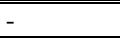 & Very hard & 0 & 0 & 2 & 10 & \\
\hline - & $\begin{array}{lll}\text { Very } & \text { hard almost }\end{array}$ & 0 & 0 & 1 & 5 & \\
\hline
\end{tabular}

* Significant difference at $\mathbf{P}$ level at $\leq \mathbf{0 . 0 5}$

Table 5: Illustrates comparison between the pre and post-performance exercise for the study group in relation to physical exercise parameters during hospitalization. The table revealed that, $50 \%$ of the study group blood pressure did not show remarkable change post performing exercises. In relation to respiratory rate the table showed that, half of the study group patients had no change in respiratory rate post performing exercise it ranged between $10>20$ cycles/minute. In addition, more than half $(57.5 \%)$ of study group patients had heart rate ranged between $80>100$ beat/minute post performing exercise. Considering body temperature, half of the study group patients did not reveal change post performing exercise, it remained $36^{\circ} \mathrm{C}>37^{\circ} \mathrm{C}$. As regards patient complains, this table revealed that, the percentage of patients who did not complain pre performing exercise were increased from $55 \%$ to $80 \%$ post performed it, while the percentage of patients who complain from pain in chest were decreased from $15 \%$ to $10 \%$ post performing exercise. However, a statistically significant difference was found only between pre and post performing exercise within the study group in relation to patient complains namely; dizziness, pallor and pain in chest $\mathrm{Z}=(0.03)$. 
Table 5: Comparison between the Pre and Post Performance Exercise for the Study Group in relation to Physical Exercise Parameters during Hospitalization.

\begin{tabular}{|c|c|c|c|c|c|}
\hline \multirow{3}{*}{ Physical exercise parameters } & \multicolumn{5}{|c|}{ Study group $n=20$} \\
\hline & \multicolumn{2}{|c|}{$\begin{array}{c}\text { Pre performing } \\
\text { exercises }\end{array}$} & \multicolumn{2}{|c|}{$\begin{array}{c}\begin{array}{c}\text { Post performing } \\
\text { exercises }\end{array} \\
\end{array}$} & \multirow{2}{*}{$\begin{array}{l}\text { Z -test } \\
\text { (P) }\end{array}$} \\
\hline & NO. & $\%$ & NO. & $\%$ & \\
\hline $\begin{array}{ll}\text { Blood pressure } / \mathrm{mmHg} \\
\text { - } & 100 / 60>120 / 80 \\
\text { - } & 120 / 80>140 / 100 \\
\text { - } & 140 / 100 \\
\end{array}$ & $\begin{array}{l}10 \\
8 \\
2 \\
\end{array}$ & $\begin{array}{l}50 \\
40 \\
10 \\
\end{array}$ & $\begin{array}{c}10 \\
8 \\
2 \\
\end{array}$ & $\begin{array}{l}50 \\
40 \\
10 \\
\end{array}$ & $\begin{array}{l}1.6 \\
0.1 \\
0.1 \\
\end{array}$ \\
\hline $\begin{array}{ll}\text { Respiratory rate/ cycle/minute } \\
\text { - } & 10>20 \\
\text { - } & 20<30 \\
\text { - } & 30+ \\
\end{array}$ & $\begin{array}{c}11 \\
7 \\
2 \\
\end{array}$ & $\begin{array}{l}55 \\
35 \\
10 \\
\end{array}$ & $\begin{array}{c}10 \\
9 \\
1 \\
\end{array}$ & $\begin{array}{c}50 \\
45 \\
5 \\
\end{array}$ & $\begin{array}{l}0.5 \\
0.5 \\
0.5 \\
\end{array}$ \\
\hline $\begin{array}{ll}\text { Heart rate/ beat/minute } \\
\text { - } & 60<80 \\
\text { - } & 80<100 \\
\text { - } & 100+ \\
\end{array}$ & $\begin{array}{c}7 \\
11 \\
2 \\
\end{array}$ & $\begin{array}{l}35 \\
55 \\
10 \\
\end{array}$ & $\begin{array}{c}7 \\
11 \\
2 \\
\end{array}$ & $\begin{array}{l}35 \\
55 \\
10 \\
\end{array}$ & $\begin{array}{l}1 \\
0.3 \\
0.3 \\
\end{array}$ \\
\hline $\begin{array}{lc}\text { Body temperature } /{ }^{\circ} \mathrm{C} \\
\text { - } & 36>37 \\
\text { - } & 37+ \\
\end{array}$ & $\begin{array}{c}13 \\
7 \\
\end{array}$ & $\begin{array}{l}65 \\
35 \\
\end{array}$ & $\begin{array}{l}10 \\
10 \\
\end{array}$ & $\begin{array}{l}50 \\
50 \\
\end{array}$ & $\begin{array}{l}1.6 \\
0.1 \\
\end{array}$ \\
\hline $\begin{array}{ll}\text { Patient complain } \\
\text { - } & \text { No complain } \\
\text { - } & \text { Dizziness } \\
\text { - } & \text { Pallor } \\
\text { - } & \text { Pain in chest } \\
\end{array}$ & $\begin{array}{l}11 \\
3 \\
3 \\
3 \\
\end{array}$ & $\begin{array}{l}55 \\
15 \\
15 \\
15 \\
\end{array}$ & $\begin{array}{c}16 \\
0 \\
2 \\
2 \\
\end{array}$ & $\begin{array}{c}80 \\
0 \\
10 \\
10 \\
\end{array}$ & $\begin{array}{c}2.1 \\
0.03 * \\
0.03 * \\
0.03 * \\
\end{array}$ \\
\hline
\end{tabular}

\section{* Significant difference at $P$ level at $\leq 0.05$}

Table 6: Illustrates comparison between mean score, standard deviation among the study and control groups in relation to the following therapeutic regimen during follow up periods. It was observed that, the difference between mean score of patient adherence to following therapeutic regimen during follow up periods were statistically significant difference regards patients prescribed diet, smoking and activity.

Table 6: Comparison between Mean Score, Standard Deviation among the Study Group in Relation to Following Therapeutic Regimen during Follow up Periods

\begin{tabular}{|c|c|c|c|c|c|c|c|c|c|c|c|c|c|c|}
\hline \multirow{4}{*}{ Items of therapeutic regimen } & \multicolumn{14}{|c|}{ Study group (follow up period) $n=20$} \\
\hline & \multicolumn{4}{|c|}{ Immediate postoperative } & \multicolumn{4}{|c|}{$\begin{array}{c}\text { Two weels post hospital } \\
\text { discharge }\end{array}$} & \multicolumn{4}{|c|}{\begin{tabular}{|c|}
$\begin{array}{c}\text { Oue mouth post hospital } \\
\text { discharge }\end{array}$ \\
\end{tabular}} & \multirow{2}{*}{\multicolumn{2}{|c|}{$\mathrm{Z}$ - test $(\mathrm{P})$}} \\
\hline & \multicolumn{2}{|c|}{ Mean } & \multicolumn{2}{|c|}{ SD } & \multicolumn{2}{|c|}{ Mean } & \multicolumn{2}{|c|}{ SD } & \multicolumn{2}{|c|}{ Meau } & \multicolumn{2}{|c|}{ SD } & & \\
\hline & $\begin{array}{l}\text { Study } \\
n=20\end{array}$ & \begin{tabular}{|c|} 
Control \\
$n=20$
\end{tabular} & \begin{tabular}{|l|} 
Strudy \\
$n=20$
\end{tabular} & \begin{tabular}{|c|} 
Contro: \\
$n=20$
\end{tabular} & \begin{tabular}{|l||} 
Study \\
$n=20$
\end{tabular} & \begin{tabular}{|c|} 
Contro1 \\
$n=20$
\end{tabular} & $\begin{array}{l}\text { Study } \\
n=20\end{array}$ & $\begin{array}{l}\text { Contro1 } \\
n=20\end{array}$ & \begin{tabular}{|l|} 
Study \\
$n=20$
\end{tabular} & \begin{tabular}{|c|} 
Contro1 \\
$n=20$
\end{tabular} & $\begin{array}{l}\text { Strdy } \\
n=20\end{array}$ & \begin{tabular}{|c|} 
Control \\
$n=20$
\end{tabular} & $\begin{array}{l}\text { Study } \\
n=20\end{array}$ & $\begin{array}{c}\text { Control } \\
n=20\end{array}$ \\
\hline $\begin{array}{l}\text { Diet } \\
\text { Smoling } \\
\text { Activity } \\
\text { Medication }\end{array}$ & $\begin{array}{l}34.12 \\
18.47 \\
30.62 \\
41.12\end{array}$ & $\begin{array}{c}26.27 \\
17.12 \\
30.6 \\
1.7\end{array}$ & $\begin{array}{l}1.74 \\
1.08 \\
6.87 \\
1.06\end{array}$ & $\begin{array}{l}2.58 \\
1.71 \\
6.8 \\
1.9\end{array}$ & $\begin{array}{c}34.57 \\
18.17 \\
31.72 \\
457\end{array}$ & $\begin{array}{c}22.70 \\
18.67 \\
2.1 \\
28.3\end{array}$ & $\begin{array}{l}3.79 \\
1.55 \\
4.09 \\
1.06\end{array}$ & $\begin{array}{l}2.37 \\
2.08 \\
2.58 \\
2.0\end{array}$ & $\begin{array}{c}31.57 \\
17.75 \\
3325 \\
420\end{array}$ & $\begin{array}{c}20.70 \\
15.08 \\
22.70 \\
1.5\end{array}$ & $\begin{array}{l}3.79 \\
1.58 \\
4.38 \\
1.52\end{array}$ & $\begin{array}{l}2.37 \\
3.05 \\
2.37 \\
1.2\end{array}$ & $\begin{array}{l}4.4(0.0)^{*} \\
3.5(0.0)^{*} \\
3.8(0.00)^{*} \\
4.5(0.00)^{*}\end{array}$ & $\begin{array}{c}6.94(0.00)^{*} \\
3.7(0.00)^{*} \\
1.9(0.04)^{\circ} \\
3.05(0.00)^{*}\end{array}$ \\
\hline
\end{tabular}

* Significant difference at $\mathrm{P}$ level at $\leq \mathbf{0 . 0 5}$

Table 7: Illustrates Comparison of physical recovery outcome parameters between the study and control groups during the follow up periods. Regarding the study group, the table showed that, there was no statistical significant difference in recovery outcome parameters during follow up periods in relation to body weight and blood pressure (1.03 and 4.78) respectively. In relation to control group; there were statistical significant differences during follow up periods in recovery outcome parameters related to muscle strength $\mathrm{X}^{2}=$

Table 7: Comparison of Physical Recovery Outcome Parameters between the Study and Control Groups during the Follow up Periods.

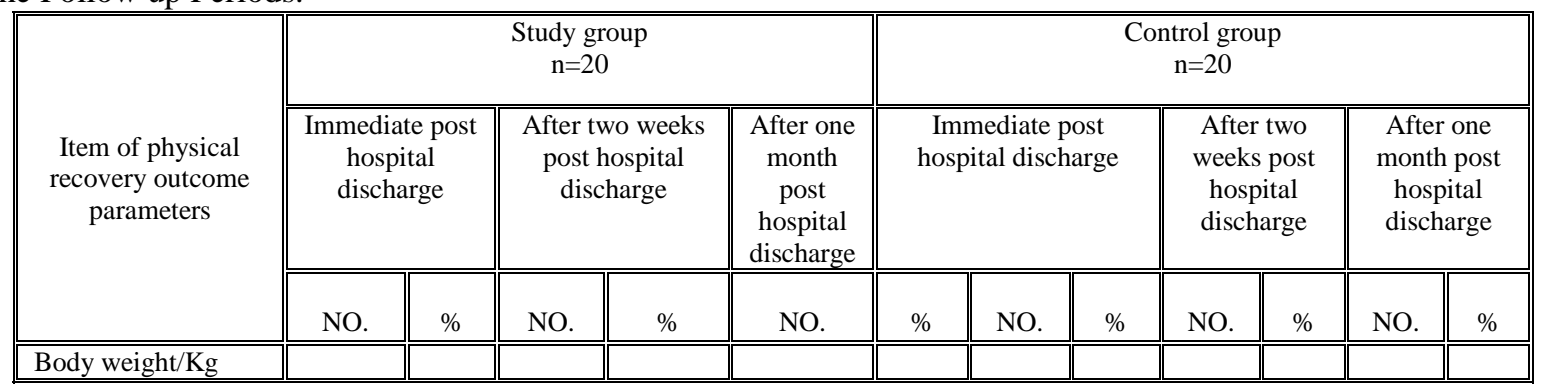


Effect of Standardized Nursing Interventions on the Recovery Outcomes of Patients Undergoing

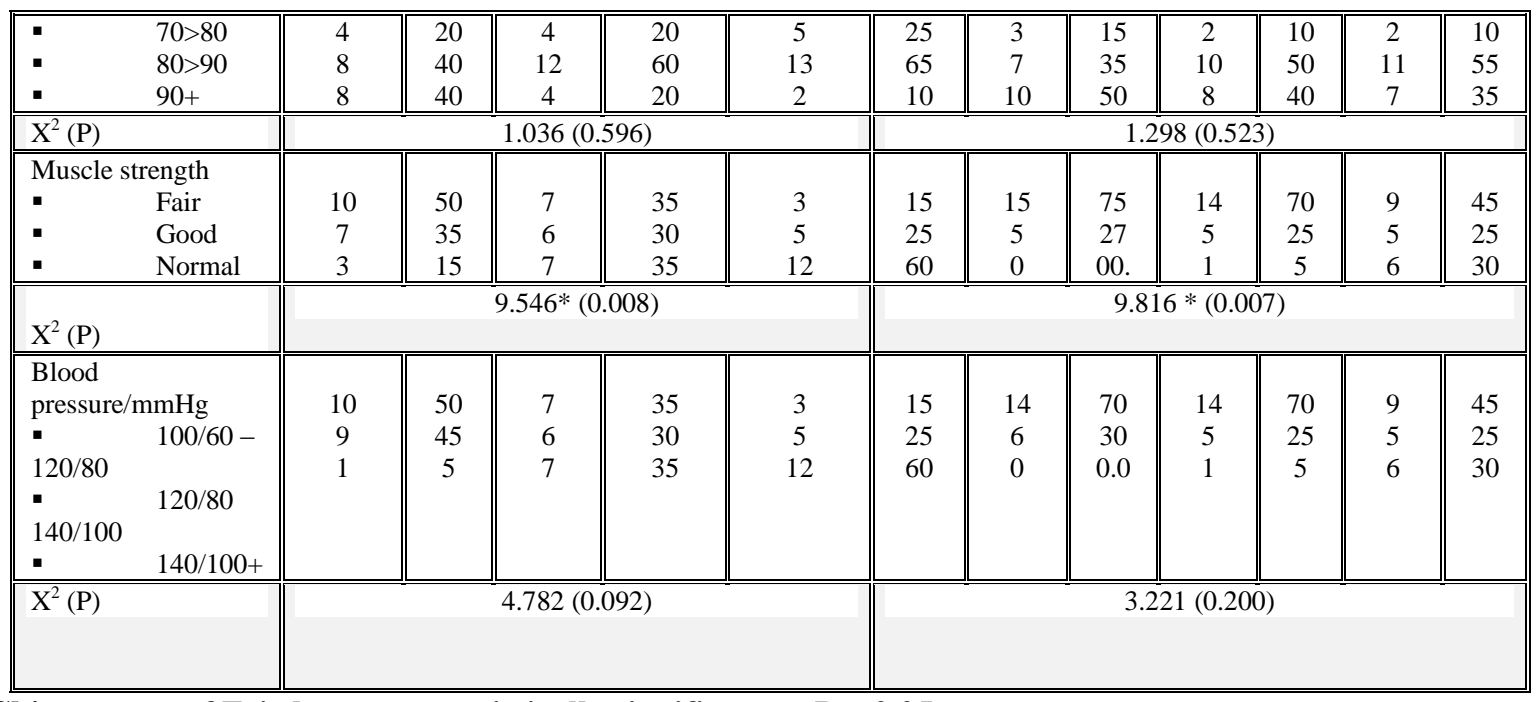

Chi - square of Friedman test statistically significant at $\mathrm{P} \leq 0.05$

Table 8: Illustrates Comparison between the study and control groups in relation to following the therapeutic regimen before applying standardized nursing interventions and during the follow up periods. Regarding pre applied nursing intervention the table showed that, the differences between mean scores of the study and control groups were not statistically significant in all items of therapeutic regimen. On the other hand, The differences between mean scores of the study and control groups immediate post applying nursing intervention were statistically significant in all items of therapeutic regimen including diet, smoking, activity and medication $\mathrm{t}=$ (15.9, 4.2, 9.5 and 6.6). At the two weeks post hospital discharge the difference between mean score of the study and control groups was not statistically significant in smoking $t=(1.2)$. Moreover, there were statistically significant differences between mean scores of the study and control groups after one month post hospital discharge in all items of therapeutic regimen including diet, quit smoking, perform activity and follow the prescribed medication.

Table 8: Comparison between the Study and Control Groups in relation to following the Therapeutic Regimen before Applying Standardized Nursing Interventions and during the Follow up Periods

\begin{tabular}{|c|c|c|c|c|c|c|c|c|c|c|c|c|c|c|c|c|c|c|c|c|}
\hline \multirow{3}{*}{$\begin{array}{l}\text { Item of } \\
\text { thercpoutic } \\
\text { regimen }\end{array}$} & \multicolumn{5}{|c|}{ Pre following } & \multicolumn{5}{|c|}{ Immadizte postoperztive } & \multicolumn{5}{|c|}{ Two watks post hospital discharge } & \multicolumn{5}{|c|}{ One month post hospital dischurg } \\
\hline & \multicolumn{2}{|c|}{$\begin{array}{c}\begin{array}{c}\text { Contro! group } \\
n=20\end{array} \\
\text {. }\end{array}$} & \multicolumn{3}{|c|}{$\begin{array}{c}\begin{array}{c}\text { Study group } \\
n=20\end{array} \\
\end{array}$} & \multicolumn{2}{|c|}{$\begin{array}{c}\text { Coszon } 5040 \\
n=20\end{array}$} & \multicolumn{3}{|c|}{$\begin{array}{c}\text { Study group } \\
n=20\end{array}$} & \multicolumn{2}{|c|}{$\begin{array}{c}\text { Comron } \\
n=20\end{array}$} & \multicolumn{3}{|c|}{$\begin{array}{c}\text { Study group } \\
n=20\end{array}$} & \multicolumn{2}{|c|}{$\begin{array}{c}\operatorname{Cos}_{n=1504} \\
n=20\end{array}$} & \multicolumn{3}{|c|}{$\begin{array}{c}\text { Study group } \\
n=20\end{array}$} \\
\hline & Mesm & 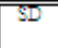 & Mang & $\overline{S \mathrm{SD}}$ & $\begin{array}{c}\mathrm{t} \\
\text { test }\end{array}$ & Mann & 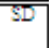 & Nasm & $\mid \overline{S D}$ & $\begin{array}{c}\mathrm{t} \\
\text { tast }\end{array}$ & Masn & SD & Masm & $\overline{S D}$ & 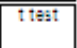 & Mem & SD & $\sqrt{\operatorname{Nosen}}$ & SD & t that \\
\hline Dist & 20.60 & 7.60 & 2138 & 509 & $\begin{array}{l}0.536 \\
(0.594) \\
\end{array}$ & 3412 & 1.74 & 2627 & 258 & $\begin{array}{l}159 \\
(0.00)^{*}\end{array}$ & 315 & 3.79 & 22.70 & 237 & $\begin{array}{l}125 \\
(0.00)^{*}\end{array}$ & 315 & 3.7 & 20.7 & 237 & $\begin{array}{l}125 \\
(0.00)^{*}\end{array}$ \\
\hline Smoking & 608 & $180^{\circ}$ & 5.75 & 1.47 & $\begin{array}{l}095 \\
(0.344)\end{array}$ & 18.47 & 108 & 172 & 1.7 & $\begin{array}{l}42 \\
(0.00)^{\circ}\end{array}$ & 18.17 & 155 & 1767 & 208 & $\begin{array}{l}1.2 \\
0.20)\end{array}$ & 1777 & 1.58 & 1508 & 15 & $\left(\begin{array}{c}49 \\
(0,00)^{*}\end{array}\right.$ \\
\hline Activity & 43,45 & 13.47 & 43.45 & 1320 & $\begin{array}{l}0.00 \\
(1.00)\end{array}$ & 3002 & 6.87 & 30.6 & 68 & $\begin{array}{l}9.5 \\
(0.00) *\end{array}$ & 31.72 & 404 & 2627 & 258 & $\begin{array}{l}143 \\
(0.00) *\end{array}$ & 3325 & 438 & 22.70 & 237 & $\begin{array}{l}9.4 \\
(0,00)^{*}\end{array}$ \\
\hline Madication & 5.70 & 2.12 & 585 & 202 & $\begin{array}{l}032 \\
0075\end{array}$ & 4.12 & 1006 & 1.7 & 19 & $\begin{array}{l}6.6 \\
(000) *\end{array}$ & 457 & 1006 & 21.1 & 20 & $\begin{array}{ll}3.1 \\
0000 * *\end{array}$ & 4220 & 152 & 1.5 & 1.5 & $\begin{array}{c}49 \\
000\end{array}$ \\
\hline
\end{tabular}

Statistically significant at $P \leq \mathbf{0 . 0 5}$

Table 9: Illustrates the comparison between the study and control groups in relation to physical recovery outcome parameters before applying standardized nursing interventions and during the follow up periods. The table showed that there were statistically significant difference between the study and control group patients in relation to their body weight at two weeks and one month post hospital discharge $\mathrm{P}=0.01$. As comparing between study and control group patients in relation to physical recovery outcome parameters the table revealed that the value of $\mathrm{P}$ were statistically significant in follow up periods at immediate, after two weeks and after one month post hospital discharge of the items of patients' muscles strength and blood pressure $\mathrm{P}=0.00$. 
Table 9: Comparison between the Study and Control Groups in relation to Recovery Outcome Parameters before Applying Standardized Nursing Interventions and during the Follow up Periods

\begin{tabular}{|c|c|c|c|c|c|c|c|c|c|c|c|c|c|c|c|c|c|c|c|c|}
\hline \multirow{3}{*}{$\begin{array}{l}\text { Items of physical racovery } \\
\text { outcome puremeters }\end{array}$} & \multicolumn{5}{|c|}{$\begin{array}{l}\text { Before epplying standardizsd } \\
\text { nursinginterventions }\end{array}$} & \multicolumn{5}{|c|}{ Immadizta postoperativa } & \multicolumn{5}{|c|}{ Two watks post hospital discherge } & \multicolumn{5}{|c|}{ One month post hospital discherge } \\
\hline & \multicolumn{2}{|c|}{$\begin{array}{l}\text { Study } \\
\text { group } \\
n=20\end{array}$} & \multicolumn{2}{|c|}{$\begin{array}{c}\text { Control } \\
\text { proup } \\
n=20\end{array}$} & \multirow[t]{2}{*}{$\begin{array}{l}\mathrm{X}^{2} \\
(\mathrm{P})\end{array}$} & \multicolumn{2}{|c|}{$\begin{array}{l}\text { Sudy } \\
\text { group } \\
n=20\end{array}$} & \multicolumn{2}{|c|}{$\begin{array}{c}\text { Control } \\
\text { group } \\
n=20 \\
\end{array}$} & \multirow{2}{*}{$\begin{array}{l}\mathrm{X}^{2} \\
(\mathrm{P})\end{array}$} & \multicolumn{2}{|c|}{$\begin{array}{l}\text { Study } \\
\text { group } \\
n=20\end{array}$} & \multicolumn{2}{|c|}{$\begin{array}{l}\text { Control } \\
\text { proup } \\
n=20\end{array}$} & \multirow[t]{2}{*}{$\begin{array}{l}\mathrm{X}^{2} \\
(\mathrm{P})\end{array}$} & \multicolumn{2}{|c|}{$\begin{array}{l}\text { Study } \\
\text { group } \\
n=20\end{array}$} & \multicolumn{2}{|c|}{$\begin{array}{c}\text { Contro1 } \\
\text { group } \\
n=20\end{array}$} & \multirow{2}{*}{$\begin{array}{l}\mathrm{X}^{2} \\
(\mathrm{P})\end{array}$} \\
\hline & NO. & $\%$ & NO. & $\%$ & & NO. & 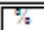 & NO. & $\%$ & & NO. & $\%$ & No. & $\%$ & & No. & $\%$ & NO & $7 \%$ & \\
\hline $\begin{array}{l}\text { Body weight } \mathrm{Kg} \\
: 70>80 \\
: 80>90 \\
.90+ \\
\end{array}$ & $\begin{array}{c}3 \\
7 \\
10 \\
\end{array}$ & $\begin{array}{l}15 \\
35 \\
50 \\
\end{array}$ & $\begin{array}{l}4 \\
8 \\
8\end{array}$ & $\begin{array}{l}20 \\
40 \\
40 \\
\end{array}$ & $\begin{array}{l}1.5 \\
(0.4)\end{array}$ & $\begin{array}{l}4 \\
8 \\
8 \\
\end{array}$ & $\begin{array}{l}20 \\
40 \\
40\end{array}$ & $\begin{array}{c}2 \\
8 \\
10\end{array}$ & $\begin{array}{l}10 \\
40 \\
50\end{array}$ & $\begin{array}{l}1.5 \\
(0.4)\end{array}$ & $\begin{array}{r}4 \\
12 \\
4\end{array}$ & $\begin{array}{l}20 \\
60 \\
20 \\
\end{array}$ & $\begin{array}{c}2 \\
10 \\
8\end{array}$ & \begin{tabular}{|l|}
10 \\
50 \\
40 \\
\end{tabular} & $(0.01)^{4}$ & $\begin{array}{c}4 \\
14 \\
2 \\
\end{array}$ & $\begin{array}{l}20 \\
70 \\
10\end{array}$ & $\begin{array}{c}2 \\
11 \\
7\end{array}$ & \begin{tabular}{|l|}
10 \\
55 \\
35 \\
\end{tabular} & $(0.01)^{7.4}$ \\
\hline $\begin{array}{l}\text { Muscle strengh } \\
\text { - Fuir } \\
\text { - Good } \\
\text { - Normal }\end{array}$ & $\begin{array}{l}14 \\
6 \\
0\end{array}$ & $\begin{array}{l}70 \\
30 \\
0.0\end{array}$ & $\begin{array}{l}10 \\
7 \\
3\end{array}$ & $\begin{array}{l}50 \\
35 \\
15 \\
\end{array}$ & $\begin{array}{l}7.1 \\
(0.2)\end{array}$ & $\begin{array}{c}10 \\
8 \\
2 \\
\end{array}$ & $\begin{array}{l}50 \\
40 \\
10 \\
\end{array}$ & $\begin{array}{l}15 \\
5 \\
0 \\
\end{array}$ & $\begin{array}{l}75 \\
25 \\
0.0\end{array}$ & $(0.00)^{*}$ & $\begin{array}{l}6 \\
6 \\
8 \\
\end{array}$ & $\begin{array}{l}30 \\
30 \\
40 \\
\end{array}$ & $\begin{array}{l}14 \\
5 \\
1 \\
\end{array}$ & $\begin{array}{r}70 \\
25 \\
5 \\
\end{array}$ & $\frac{11.25}{(0.00)^{*}}$ & $\begin{array}{c}3 \\
5 \\
12 \\
\end{array}$ & $\begin{array}{l}15 \\
25 \\
60\end{array}$ & $\begin{array}{l}9 \\
5 \\
6 \\
\end{array}$ & $\begin{array}{l}45 \\
25 \\
30 \\
\end{array}$ & $\begin{array}{c}8.7 \\
(0.01)^{*}\end{array}$ \\
\hline $\begin{array}{l}\text { Blood presture mmHg } \\
100 / 60120 / 80 \\
120 / 80-140 / 100 \\
140 / 100+ \\
\end{array}$ & $\begin{array}{l}7 \\
8 \\
5 \\
\end{array}$ & $\begin{array}{l}35 \\
40 \\
25 \\
\end{array}$ & $\begin{array}{l}10 \\
9 \\
1 \\
\end{array}$ & $\begin{array}{c}50 \\
45 \\
5\end{array}$ & $\begin{array}{l}2.07 \\
(0.4)\end{array}$ & $\begin{array}{c}10 \\
9 \\
1 \\
\end{array}$ & $\begin{array}{r}50 \\
45 \\
5 \\
\end{array}$ & $\begin{array}{c}7 \\
10 \\
3 \\
\end{array}$ & $\begin{array}{l}35 \\
50 \\
15\end{array}$ & $(0.04)^{2}$ & $\begin{array}{r}13 \\
6 \\
1 \\
\end{array}$ & $\begin{array}{c}65 \\
30 \\
5 \\
\end{array}$ & $\begin{array}{c}6 \\
10 \\
4 \\
\end{array}$ & $\begin{array}{l}30 \\
50 \\
20 \\
\end{array}$ & $\begin{array}{l}10.44 \\
(00.00)^{*}\end{array}$ & $\begin{array}{c}6 \\
12 \\
2 \\
\end{array}$ & $\begin{array}{l}30 \\
60 \\
10\end{array}$ & $\begin{array}{l}5 \\
8 \\
7\end{array}$ & $\begin{array}{l}25 \\
40 \\
35 \\
\end{array}$ & $(0.02)^{72}$ \\
\hline
\end{tabular}

\section{Statistically significant at $P \leq 0.05$}

Table 10: Illustrates the correlation between mean score standard deviation of study group in relation to follow the prescribed diet and physical recovery outcome parameters immediate post and one month post hospital discharge. The table showed that, there was no statistically correlation between prescribed diet and all aspects of patients' physical recovery outcome parameters of the study group immediate after applied standardized nursing interventions.

Table 10: Correlation between Mean Score Standard deviation of Study Group in relation to Following the Prescribed Diet and Physical Recovery Outcome Parameters Immediate Post and One Month Post Hospital

\begin{tabular}{|c|c|c|c|c|c|c|}
\hline \multirow{4}{*}{$\begin{array}{l}\text { Items of physical outcome } \\
\text { parameters }\end{array}$} & \multicolumn{6}{|c|}{ Study group $n=20$} \\
\hline & \multicolumn{6}{|c|}{ Follow the prescribed diat } \\
\hline & \multicolumn{3}{|c|}{$\begin{array}{c}\text { Immediate after applied standardizad } \\
\text { nuraing interventions }\end{array}$} & \multicolumn{3}{|c|}{ One month after applied standardizad nursing interventions } \\
\hline & Mean & SD & $\begin{array}{l}\text { Comelation I } \\
\text { (P) } \\
\end{array}$ & Mean & SD & $\begin{array}{l}\text { Correlation I } \\
\text { (P) }\end{array}$ \\
\hline 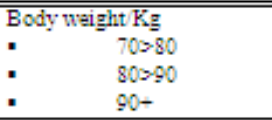 & $\begin{array}{l}47.56 \\
47.40 \\
48.25\end{array}$ & $\begin{array}{l}2.128 \\
1.765 \\
2.176\end{array}$ & $\begin{array}{l}0.135 \\
(0.406)\end{array}$ & $\begin{array}{l}31.73 \\
31.38 \\
31.58\end{array}$ & $\begin{array}{l}3.731 \\
3.828 \\
3.795\end{array}$ & $\begin{array}{l}-0.027 \\
(0.871)\end{array}$ \\
\hline $\begin{array}{lc}\text { Muscle strength } \\
: & \text { Fair } \\
: & \text { Good } \\
\text { - } & \text { Nonnal } \\
\end{array}$ & $\begin{array}{l}47.25 \\
47.87 \\
49.60 \\
\end{array}$ & $\begin{array}{l}2.074 \\
1.846 \\
1.140\end{array}$ & $\begin{array}{c}0.312 \\
(0.060)\end{array}$ & $\begin{array}{l}31.35 \\
33.80 \\
25.80 \\
\end{array}$ & $\begin{array}{l}3.774 \\
1.656 \\
1.643 \\
\end{array}$ & $\begin{array}{l}-0.025 \\
(0.878)\end{array}$ \\
\hline
\end{tabular}

Person coefficient for correlation

* statistically significant at $\mathrm{P} \leq 0.05$

\section{Discussion}

Thoracic surgery is an invasive procedure performed on thoracic cage to diagnose or treat illness, correct deformities and defects, repair injuries, and cure certain diseases. Nurses assume important active roles in caring for patients before, during and after thoracic surgeries; collaborative and independent nursing care prevents complications and promotes optimal outcome for the thoracic surgical patients. Thoracic surgical nurses have a direct role in patients' early recovery outcome after ${ }^{(1,30)}$.

In the present study, it was found that, there was no significant difference in sociodemographic data between study and control groups. Moreover, the results revealed that, about half of total studied patients were in age of more than 50 years old. These findings were in same line Jeunifer $(2010){ }^{(31)}$ who found that thoracic surgeries are performed for patients who are older than 55 years old. Also, it was not congruent with findings of Grodstein et al (2007) ${ }^{(32)}$ who illustrated that; thoracic surgeries are widely performed in advanced age.

Furthermore, the findings of the present study showed that, the prevalence of thoracic surgeries was grater in males three times in females. This result was in the same line with Shirely and Charlson $(2010){ }^{(33)}$ and Aydin (2011) ${ }^{(34)}$ who found men have a higher rate of thoracic surgeries than women. Moreover, the present study indicated that most of the studied patients were married, had elementary education, skilled occupation, and had not enough income. In this respect, Mellville and Hampton (2009) ${ }^{(35)}$ and Charlson and Isam (2010) ${ }^{(11)}$ clarified that, the level of education and nature of work had an effect on behavior of patients to accept their illness.

Lifestyle of thoracic surgery patients had direct effect on the progress of recovery outcome after thoracic surgery. Early assessment for patients habits are important in changing their behavior and reduce risk factors. In the present study, there was no significant difference found between the studies patients in both 
groups regarding their health habits. Most of total studied patients were smokers, carry heavy objects and did not practice exercises. Moreover, the majority of them did not take the medication on time. These results in agreement with Grundy et al (2007) ${ }^{(36)}$ who found that, cigarette smoking, lacking of activity and sedentary lifestyle are considered risk modifiable factors having an effect on thoracic surgery recovery, which enhancing narrowing of arterial walls and eventually restricting blood flow. Therefore, Parent and Fortin (2008) (37) recommended that, the nurse needs to know as much as possible about patients' health habits and be knowledgeable about modifiable lifestyle changes to be able to write a realistic relevant plan.

As regards patients' knowledge about therapeutic regimen, the results of the present study revealed that, most of the studied patients in both study and control groups had poor knowledge about modifiable lifestyle changes related to diet, exercises, smoking and medication after surgery. This result was in agreement with Bedier (2005) ${ }^{(38)}$ who refer to patients' inability to resume former level of physical activity and lack of coping with changes in their life to low level of patients' awareness about their condition and lack of knowledge about postoperative care which predict poor recovery outcome.

Preoperatively, the result of the present study showed that, before applying standardized nursing interventions there were no significant differences between study and control groups regarding following therapeutic regimen in all of its items. This findings may be attributed to the fact that, the patients of the present study were equally had low locus of control and did not aware that therapeutic regimen should be followed after thoracic surgery.

In postoperative period, immediately after applying standardized nursing interventions (before hospital discharge) study group had a highly significant improvement than those of control group in relation to following all aspects of therapeutic regimen. This may be related to the reinforcement and motivation that given to patients of the study group through consecutive sessions of standardized nursing interventions, using illustrated manual with simple information about therapeutic regime, demonstrating and performing prescribed exercises. In this respect Jeunifer (2010) ${ }^{(31)}$ found that, applying standardized nursing interventions postoperatively plays a major role in patients recovery, self-motivation, increasing locus of control and readjustment and direct the internal desire to a positive way. Hilton et al (2009) ${ }^{(39)}$ indicated that, the mean desire score in hospital were the same for both groups to follow prescribed regimen.

Regarding postoperative activities Charlson and Isam (2010) ${ }^{(11)}$ stressed that, following the thoracic surgery, the patient must encouraged to slowly resume an active life, while minimize the risk associated with overexertion. These activities include movement in bed; perform postoperative exercises which increase endurance, strength and flexibility of joints and muscles. In addition, improve functioning of heart and lungs, decrease patients complain, improve vital signs and circulating system.

On the other hand, Gerald and Fletcher $(2011)^{(40)}$ illustrated that, active but not resistive range of motion of the extremities is also well tolerated early after thoracic surgery as long as activities do not stress or impair healing of sternal incision, while patient become stable and early ambulated from bed. This is in agreement with the result of the present study which revealed that, the exertion level for patients in the study group during performing postoperative exercise were significantly decreased at the third day than first post performing exercises. In other words, about half of the study group had moderate exertion during performing exercise in the first day of performing exercise, while less than quarter of them had the same level of exertion at third day. Furthermore, most of the patients in the study group had normal complete range of motion against gravity with resistance after performing postoperative exercise. In addition, there was significant improvement in physical outcome parameters within study group after performing postoperative exercise. In this respect Napoli (2009) ${ }^{(41)}$ and Webster and Obsorne $(2005)^{(42)}$ recommended that, performing early postoperative physical exercises improves circulation, decreases patient's complain and improves both physical and psychological functioning.

Before hospital discharge the thoracic surgery patient must have information about their new lifestyle after surgery regarding modifiable diet, smoking cessation, activities performance and taking the prescribed medications. After implementation of the standardized nursing interventions during follow up period, a modification in the study group patients' lifestyle were improved than the control group patients in relation to medication adherence, diet modification, activity tolerance and smoking cessation. This result indicated that, the importance of providing patients with simple instructions about modifiable lifestyle changes after surgery, increase patients awareness about their condition, which decrease level of anxiety about changing in roles and how to deal with their life after hospital discharge. This was supported by Aydin $(2011){ }^{(34)}$ who found that, postoperative information is a vital in nursing of thoracic surgical patients that help them to decrease level of depression and increase awareness about changes in their life.

In addition, Zilling and Lithner (2009) ${ }^{(43)}$ illustrated that, patients who undergo thoracic surgery often feel sad or depressed after leaving the hospital. These emotions may be the result of not knowing what to expect or not being able to cope with lifestyle changes such as those associated with performing personal care activities, meeting family role expectations, quitting smoking, reducing stress, return to work and resuming 
sexual relations. So, patients must be prepared for discharge by providing them with physical and emotional support before leaving hospital to increase their lifestyle changes that help them to be more familiar with their own behaviors, decrease level of anxiety and increase desire level to comply with the prescribed regimen.

On the other hand for the control group, there was significant decrease in patients' adherence for all items of therapeutic regimen. These was explained by Moore and Dalansky (2012) ${ }^{(44)}$ who stressed that, information is vital nursing interventions for thoracic surgeries patients who are unable to take active part in postoperative care they will remain passive, liable to become depressed and unable to cope with lifestyle changes.

Charlson and Isam $(2012)^{(11)}$ stated that, life style modification is recommended as the first step of non-pharmaceutical therapy after thoracic surgery. Moreover, Victor and Ferraris (2010) ${ }^{(45)}$ found that, early ambulation and following prescribed regimen as early as possible after surgery could improve clinical outcome and reduce postoperative complications.

In conclusion, applying standardized planned nursing interventions to thoracic surgeries patients' pre and postoperatively was effective in improving thoracic surgeries patients' outcome physical parameters which in turn improve their quality of life. This plan should include repeated, cleared instructions about new lifestyle changes after surgery to the patients and their families for encouraging in changing their behavior, increase locus of control and self-confidence and encourage them to cope with new lifestyle. All of these will help in early recovery both physically and psychologically.

\section{Conclusion}

Based on the findings of the present study the following were concluded:

1. Most of the study and control patients had poor knowledge about modifiable life change related to diet, exercises, smoking and medication.

2. There were highly significant improvements of the study group patients in relation to following the therapeutic regimen immediate after applying the standardized nursing interventions and after two weeks of hospital discharge.

3. Majority of patients in the study group had normal complete range of motion against gravity with full resistance after performing postoperative exercise during hospitalization.

4. There was significant improvement in physical outcome parameters (body temperature, respiration, blood pressure and no complain) within the study group patients after performing postoperative exercises.

5. There was significant improvement in the study group patients regarding their body weight; muscles strength and blood pressure after applied the standardized nursing interventions after two weeks of hospital discharge.

\section{Recommendations:}

Based on the findings of the present study, the following recommendations are suggested:

Recommendations regarding hospital administration and leadership:

1. The developed manual of basic nursing interventions for management of patients undergoing thoracic surgery should be available in the cardiothoracic surgery unit and should be revised and updated annually.

2. Provision of adequate supervision of nurses during their practice and provide teaching with motivation and feedback on performances.

Recommendation regarding nursing professionalism and practice:

1- Evaluation of personal nursing performances should be based on the attainment of the professional standards.

2- Integration of the current knowledge of nursing and management theories and concepts into the practice environment.

Recommendation regarding educational institutes:

1- A basic orientation training program should be provided to newly employed nurses in cardiothoracic surgery unit who must be examined for their knowledge and skills before assuming independent responsibilities for patient care.

2- Continuing education programs, in-service education and workshops should be planned on regular basis to nurses working on the cardiothoracic surgery unit and should be made on free days so that these programs don't interfere with nurse's clinical work schedule and each one is able to attend these programs.

Recommendations regarding research and further studies:

1- Research about developing a clinical pathway for care of thoracic surgical patients. 


\section{References}

[1]. El Shenawei H. Effect of specific nursing intervention on recovery outcomes of patients undergoing coronary artery by-pass graft surgery. Unpublished doctoral thesis, Faculty of Nursing, Alexandria University; 2008.

[2]. Burden N. Thoracic Surgeries Nursing. Philadelphia: W.B Saunders Company, 2010; 217.

[3]. American Thoracic Association. Advanced practice nursing: A new age in health care, nursing facts. Washington: American Nurses Publishing, 2013.

[4]. Bakul K. Thoracic surgeries. London: Churchill Livingstone Publishing Company. 2011; 97 - 220.

[5]. The Main University Hospital medical statistical records. Alexandria, Egypt, 2012.

[6]. Denver T. Association of Thoracic Surgery Nurses: AORN Standards, Recommended Practices, and Guidelines, 2008.

[7]. Hines R, Barash P, Watrous G, O'Connor T. R. Complications occurred in the anesthesia care unit: A survey. Anesthesia Analgesia. 2009; 74 (4): 503 - 9.

[8]. Warren T, Mary C. Thoracic surgeries nursing. London: Harper Row Company. 2008; 70 - 4.

[9]. Phillips N. Thoracic surgeries technique $10^{\text {th }}$ ed. Philadelphia: Mosby, Inc., 2011; $501-9$.

[10]. Darrel T, Welch E. Center of thoracic education: Thoracic surgery patient guide. http//www.thoracicBCCa.2009.

[11]. Charlson M, Isam W. Care after thoracic surgery. New England Journal of Medicine. 2012; 344(15): 1-13.

[12]. Henderson M.A. Essential thoracic surgeries for nurses. Landon: Churchill Livingston, 2011.

[13]. Smith R, Daper R. Who is control ? An investigation of nurse and patient beliefs related to control of their health care. Journal of Advanced Nursing 2010; 26 (6): 227 - 31.

[14]. Michael J, Zellweger R. Risk stratification in patients' early and late post thoracic surgery. American Journal of Thoracic. 2011; (37): 44-52.

[15]. Hodge D, Thoracic surgeries: A nursing approach. London: Churchill Livingstone, 2009.

[16]. Thoracic surgical unit design guidelines. Health department of Western Australia Facilities Unit, 2010.

[17]. Martin PA. American thoracic society: Thoracic surgery, gale encyclopedia of Medicine: American Thoracic Society, available at: www.Health A to Z.com, 2006, retrieved on December 2012.

[18]. June C, Margaret H. Care of the patient in thoracic surgery. $7^{\text {th }}$ ed. St. Louis: Mosby, Inc.; $1999,13$.

[19]. Abdel Mowla H. Developing nursing interventions standards for patients undergoing thoracic surgeries. Unpublished doctoral thesis, Faculty of Nursing, Alexandria University; 2012.

[20]. Maxine M, Hinze D. Nursing care management: Nursing care of patients experiencing surgery. Philadelphia: JB Lippincott Company, 2004; 1 - 26.

[21]. Honey B. British thoracic society guidelines on thoracic surgery, $2007 . \quad$ Available at http://www.thorax.bmj.com/egi/content/full/56/supp.

[22]. Frances Dm, Tanya D and Marianne D. Knowledge basic to the nursing care of adults undergoing thoracic surgery. Philadelphia: W.B. Saunders Company, 2004; 96 - 104.

[23]. Katz J, Green E. Clinical practice guidelines for the adult surgical patient. St. Louis, Mosby Company. 2009.

[24]. Groah LK. Operating room nursing: The preoperative role, Philadelphia: JB Lippincott Company, $1992 ; 416$ - 22.

[25]. Elikinmk. Nursing interventions and clinical skills. $2^{\text {nd }}$ ed. Philadelphia: Mosby Company, $2000 ; 25$ - 46.

[26]. Lovtt (1998) in American Heart Association: exercises of cardiac surgery. http://www.americanheart.org.2009.

[27]. Borg in Mitcheel R. Thoracic rehabilitation: Participating in an exercise program in a quest to survive. Rehabilitation Nursing, 1999; 24(6): 236-9.

[28]. Heitkemper M, Lewis H, Dirksen S. Medical surgical nursing assessment and management of clinical problems. $5^{\text {th }}$ ed. London, Mosby; 2010.

[29]. Cameron P, Jelinek G, Kelly A and Murray L. Textbook of adult emergency medicine. London: Churchill Livingstone, 2004.

[30]. Wasell C, Ellis H. General surgery for nurses, 2nd ed. London: Black well Scientific Publications $2009 ; 21$ - 7.

[31]. Jennifer O. Quality of life 12 months after cardiothoracic surgery. Heart and lung, 2010; 29 (6):401-10.

[32]. Grodstein F, Stampfer MJ, Colditz GA. Postmenopausal hormone therapy and mortality. New England Journal of Medicine, 2007; 336:1769-75.

[33]. Shirely M, Cornelia R. Women's pattern exercises following cardiothoracic rehabilitation. Nursing Research, $2010 ; 47$ (6):318 322.

[34]. Aydin S. Quality of life in elder after thoracic surgery. International Heart Journal. 2011; 47(1):59-65.

[35]. Mellville N, Hampton J. Quality of life four years after thoracic surgeries. Thoracic, 2009; 81:352-8.

[36]. Grundy SM, Becker D, Stone NJ. Executive summary of the third report of the National Education Treatment in Adults (Adult treatment Panel III). JAMA. 2007: 285:2486 - 97.

[37]. Parent N, Fortin F. A randomized controlled trial of vicarious through peer support for male first time thoracic surgery patients: Impact on anxiety, self-efficacy expectation and self-reported activity. Heart and lung. 2008; 29(6): 289-400.

[38]. Bedier N. Impact of health promotion for coronary heart disease patients. Bulletion of High Institute of Public Health, 2005; 35 (2): $335-56$.

[39]. Hilton S, Doherty S, Kendrick T. Promotion of health behavior among adults at increased risk of thoracic disease in general practice: methodology and base line data from the change of thoracic study. Health Education Journal, 2009; 35(2): 335-56.

[40]. Gerald F, Fletcher MD. How to implement physical activity in primary and secondary prevention after thoracic sugary. Circulation, 2011; 96:355-7.

[41]. Napoli E. Rehabilitation intervention after thoracic disease. Minerva Medicine. 2009; 91(11-12); 305-10.

[42]. Webster J, Obsorne S. Preoperative care before thoracic surgery prevents surgical site infection. Evidence Base Nursing. 2005; 9(116):106-20.

[43]. Zilling T, Lithner M. Pre and postoperative information needs. Patient Education and Counseling. 2009 ; 40: $1129-37$.

[44]. Moore SM, Dalansky MA. An audio- taped information programme after thoracic surgery improved physical functioning in women and psychological distress in men. Evidence Based Nursing. 2012; 5:93-104.

[45]. Victor A, Ferraris R. Improve clinical outcome and reduce health care cost after thoracic surgery. International Journal of Thoracic.2010: 14 (3):141-3.

[46]. Shih F. Perception of self in the intensive care unit after cardiac surgery among adult Taiwanese and American-Chinese patients. 